\title{
Mantle Cell Lymphoma: A Rare Vallecular Tumour
}

\section{Mantle Hücreli Lenfoma: Nadir Bir Vallecular Tümör}

\section{Renhui LO $\odot$, Sakinah MOHAMAD $\odot$, Madhusudhan KRISHNAMOORTHY $\odot$, Irfan MOHAMAD $\odot$, Sarah ZULKARNAIN $\odot$, Faezahtul Arbaeyah HUSSAIN $\odot$}

Ethics Committee Approval: Approval

Conflict of Interest: The authors declare that they have no conflict of interest. Funding: None.

Informed Concent: Informed consent was taken.

\section{ABSTRACT}

Vallecular lymphoma is an extremely rare tumour of oropharynx. We report a case of 61-yearold gentleman presented with severe dysphagia and globus sensation for two months. Patient underwent endoscopic transoral tumour debulking for diagnostic and therapeutic purpose. Histopathologically, patient was diagnosed as mantle cell lymphoma $(M C L)$. In this case report, atypical presentation of the disease, histopathological features and its current treatments are discussed.

Keywords: Mantle cell lymphoma, oropharynx, tumour, vallecula

öz

Vallekular lenfoma, orofarenkste son derece nadir görülen tümördür. İki aydır ciddi disfaji ve globus hissi ile başvuran 61 yaşında erkek bir hastayı sunuyoruz. Hastaya tanı ve tedavi amacıyla endoskopik transoral tümör debulking uygulandı. Histopatolojik olarak hastaya mantle hücreli lenfoma (MCL) tanısı kondu. Bu olgu sunumunda Hastalığın atipik yerleşimi, histopatolojik özellikleri ve güncel tedavileri tartışılmaktadır.

Anahtar kelimeler: Mantle hücreli lenfoma, orofarenks, tümör, vallekula
Cite as: Lo R, Mohamad S, Krishnamoorthy M, Mohamad I, Zulkarnain S, Hussain FA. Mantle cell lymphoma: A rare vallecular tumour. Medeniyet Med J. 2020;35:67-70.
Received: 22 January 2020

Accepted: 25 February 2020 Online First: 28 February 2020

Corresponding Author: S. Mohamad ORCID: 0000-0002-4388-5350 Universiti Sains Malaysia, School of Medical Sciences, Department of Otorhinolaryngology-

Head \& Neck Surgery, Kubang Kerian, Malaysia

msakinah@usm.my

R. Lo

ORCID: 0000-0001-7551-6544 Madhusudhan Krishnamoorthy ORCID: 0000-0001-6105-2881

I. Mohamad

ORCID: 0000-0001-8572-0514 Universiti Sains Malaysia, School of Medical Sciences, Department of Otorhinolaryngology-

Head \& Neck Surgery,

Kubang Kerian, Malaysia

S. Zulkarnain ORCID: 0000-0001-5736-5949

F.A. Hussain ORCID: 0000-0003-3899-8833 Universiti Sains Malaysia,

School of Medical Sciences, Department of Pathology, Kubang Kerian, Malaysia 


\section{INTRODUCTION}

Vallecula is a potential space, bounded anteriorly by base of tongue, posteriorly by lingual surface of epiglottis, medially by median glossoepiglottic fold, and laterally by lateral glossoepiglottic folds. It contains mainly glandular or lymphoid tissues. Its tumour is not among common disease entities ${ }^{1}$. The commonest vallecular mass is benign retention cyst ${ }^{2}$. Other rare causes include lingual thyroid cyst, thyroglossal cyst, minor salivary gland tumours, lipoma, schwannoma, lymphangioma, haemangioma, granulomatous or infectious diseases, malignant conditions including squamous cell carcinoma, or very rarely lymphoma ${ }^{3}$. Large vallecular tumour often has challenging airway as it often displaces epiglottis posteriorly causing airway obstruction.

\section{CASE REPORT}

A 61-year-old gentleman presented with a 2-month history of globus sensation and later worsened with incomplete swallowing. He should swallow multiple times for complete intake of food. He had no dysphagia, odynophagia, voice change, shortness of breath, B symptoms, loss of appetite or weight.

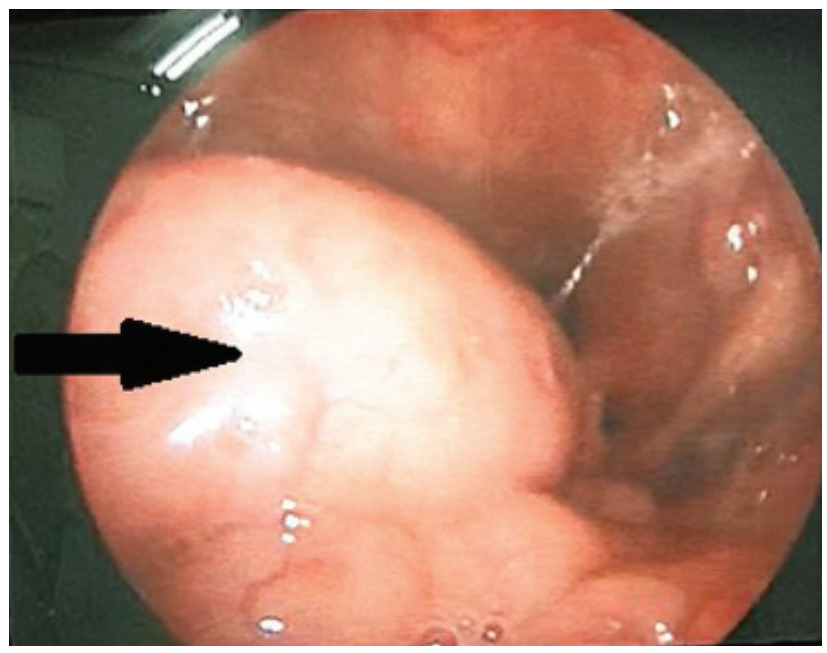

Figure 1. Right vallecular mass (arrow) with epiglottis displaced posteroinferiorly patient's consent obtained for the use of the image.
Physical examination revealed that patient was well and not in respiratory distress. Laryngoscopy revealed a globular mass arising from right vallecular area occupying $70 \%$ of the airway (Figure 1). The epiglottis was displaced posteriorly, and both vocal cords were grossly normal. There was no cervical lymphadenopathy. Axillary and inguinal lymphadenopathies, and hepatosplenomegaly were not detected.

Computed tomography (CT) scan of neck demonstrated a right vallecular mass with large lobulated homogenous enhancing soft tissue density measuring $2.2 \mathrm{~cm} \times 3.1 \mathrm{~cm} \times 2.5 \mathrm{~cm}$ and displacing epiglottis posteroinferiorly. Lymphoma or adenoid cystic carcinoma should be excluded in differential diagnosis (Figure 2).

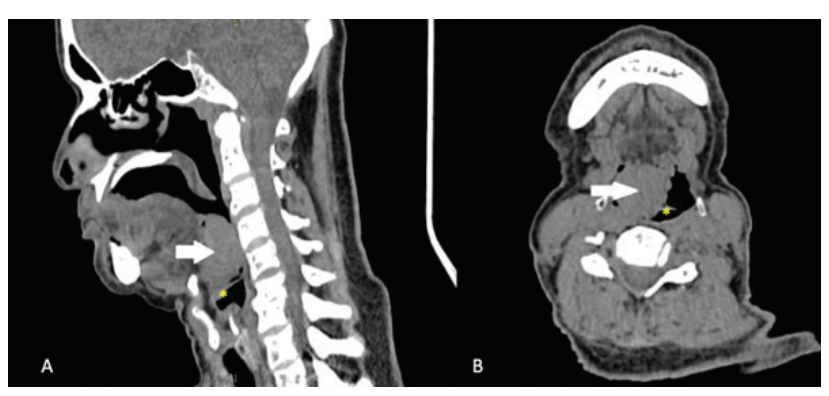

Figure 2. CT neck (A, sagital cut; B, axial cut) showing homogenously enhanced soft tissue density mass with mass effect displacing epiglottis $\left({ }^{*}\right)$ posteroinferiorly.

Direct laryngoscopy under general anaesthesia was performed. There was a globular mass at the right vallecular area. Seventy percent of the tumour bulk was removed and tissue sample was sent for histopathological examination (Figure 3). Patient has had no more difficulty in swallowing immediate after the operation. The histopathological examination showed mantle cell lymphoma (Figure 4,5) with ki67 proliferative index of $40-50 \%$. He was later referred to haematology department for further treatment. Treatment options were given to the patient, however he only opted for oral cyclophosphamide treatment. 


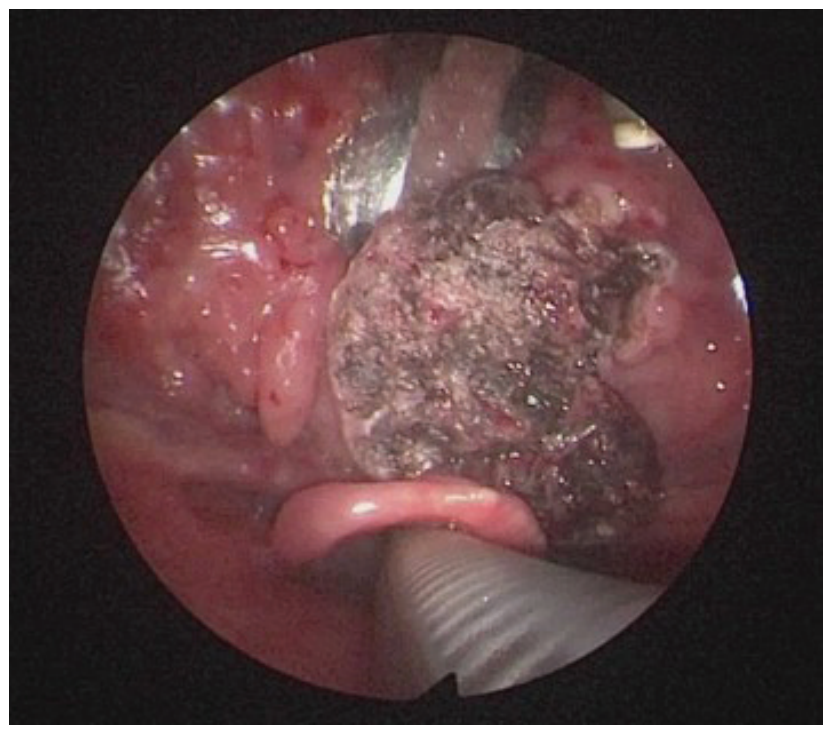

Figure 3. Post debulking and biopsy of the mass.

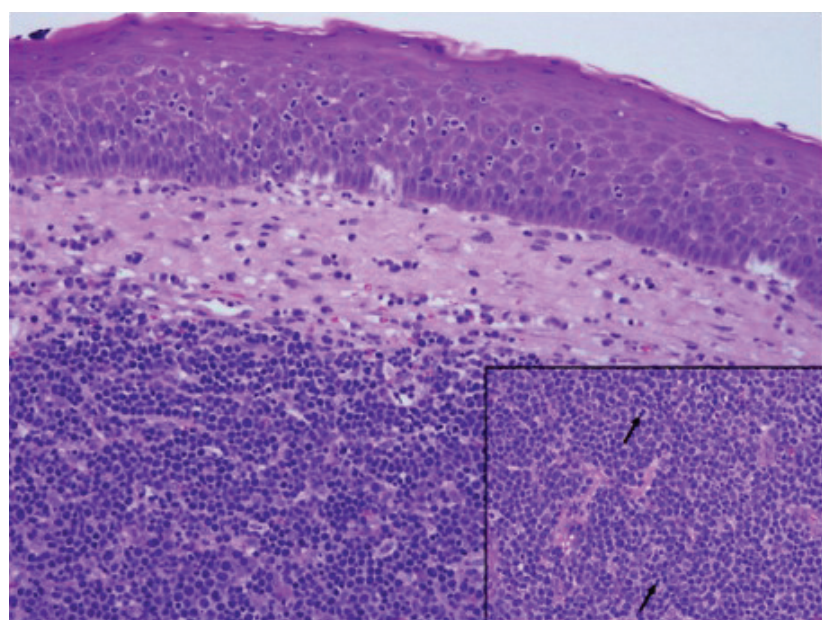

Figure 4. The vallecular tissue has benign stratified squamous epithelium with the underlying stroma diffusely infiltrated by neoplastic lymphoid cells (H\&E, 200x). The neoplastic cells are monotonous and medium cell size. The inset: They are composed of centrocytes displaying cleaved nuclei, inconspicuous nucleoli and scanty cytoplasm. Some mitotic figures are present (arrow). Reactive small lymphocytes are interspersed in between the neoplastic cells (H\&E, 400X).

\section{DISCUSSION}

Mantle cell lymphoma is a rare type of mature B-cell non-Hodgkin lymphoma (NHL). It only accounts for 3-6\% of all NHLs. Annually, it affects 0.5 in 100.000 population. Median age of diagnosis is 68 years with male predominance of $3: 1^{4}$.
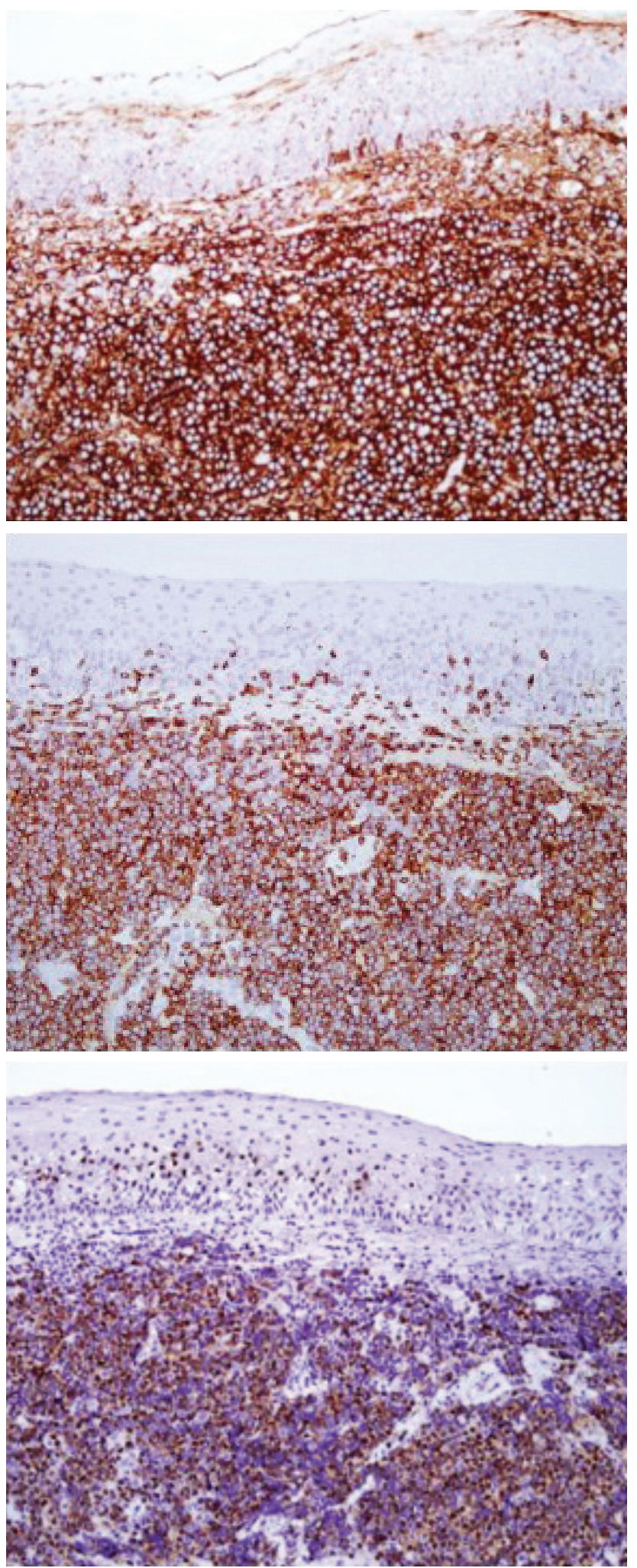

Figure 5. Immunohistochemical stains. The neoplastic cells show strong membrane staining for (A) CD 20 (200x), (B) CD $5(200 x)$ and (C) strong nuclear staining for Cyclin D1 (200x). 
Majority of the patients typically presented with generalized lymphadenopathy (75\%), while the rest with extra nodal involvement such as involvement of peripheral blood, bone marrow, gastrointestinal tract, spleen, breast, pleural and orbit $^{5}$. One-third of the patients will have B symptoms including fever, night sweats and weight loss $^{6}$. Diagnosis of $\mathrm{MCL}$ warrants tissue biopsy with demonstration of monomorphic small to medium sized centrocytes with cleaved nuclei and inconspicuous nucleoli. MCL is a mature B cell lymphoma, expressing the immunohistochemical markers of CD20, CD79a, PAX5, CD19, CD22, CD5 and overexpression of cyclin D1. MCLs stain negatively with cyclin D1, SOX11 is a useful additional marker, which can also give prognostic information $^{7}$. Cytogenetic alteration of $t(11 ; 14)$ (q13;q32) by fluorescent-in-situ hybridization is characteristic in $\mathrm{MCL}^{8}$.

In this patient, the vallecular tumour was huge. It pushed the epiglottis posteroinferiorly. A potentially acute respiratory compromised event may occur during any manipulation, including intubation for debulking surgery. Surgeon must always bear such a risk in mind and provide essential assistance or care when needed including assisting in intubation or tracheostomy under local anaesthesia. Glucocorticoid such as prednisolone or more potent dexamethasone can be given, as it is known to be able to arrest growth and induce apoptosis in lymphoid tissue?.

Mantle cell lymphoma is known to be aggressive. The median survival time is 3 to 5 years. Only 5 to 10 percent of the patients survive longer than 3 years ${ }^{10}$. Our patient's ki67 proliferative index was 40-50\%, indicating poor prognosis. Up to date, this disease is still considered incurable without any universally accepted standard of treatment. The mainstay of treatment modality is combination of chemotherapy with immunotherapy with either intensified cytarabine-based induction regimens and frontline ASCT (autologous stem cell transplant) for younger patients, or R-CHOP (Rituximab, Cyclophosphamide, Doxorubicin, Vincristine and Prednisolone) for elderly patients ${ }^{4}$. Our patient was offered R-CHOP initially, he refused and only opted for oral cyclophosphamide. He is currently still on this medication 7 months after establishment of diagnosis, under regular monitoring.

\section{CONCLUSION}

Lymphoma must be considered as one of the differential diagnosis of any vallecular mass although it is rare. It is crucial for surgeon to work closely with multidisciplinary team approach in managing airway to prevent fatal complications.

\section{REFERENCES}

1. Lahiri AK, Somashekar KK, Wittkop B, Ayshford C. Large Vallecular Masses; Differential Diagnosis and Imaging Features. J Clin Imaging Sci. 2018;8:26. [CrossRef]

2. Hoang TM, Kim BB. A Case Report of a Vallecular Cyst and Literature Review. J Oral Maxillofac Surg. 2015;73:1766. e1-1766.e17664. [CrossRef]

3. Tresley J, Saraf-Lavi E, Kryvenko ON, Sargi Z. Epiglottic masses identified on CT imaging: A case report and review of the broad differential diagnosis [published correction appears in Neuroradiol J. 2015;28:347-53. [CrossRef]

4. Cheah CY, Seymour JF, Wang ML. Mantle Cell Lymphoma. J Clin Oncol. 2016;34:1256-69. [CrossRef]

5. Argatoff LH, Connors JM, Klasa RJ, Horsman DE, Gascoyne RD. Mantle cell lymphoma: a clinicopathologic study of 80 cases. Blood. 1997;89:2067-78. [CrossRef]

6. Armitage JO, Weisenburger DD. New approach to classifying non-Hodgkin's lymphomas: clinical features of the major histologic subtypes. Non-Hodgkin's Lymphoma Classification Project. J Clin Oncol. 1998;16:2780-95. [CrossRef]

7. Jaffe E, Arber DA, Campo E, Harris NL, Quintanilla-Fend L. Hematopathology. 2nd ed. Elsevier, p:397-414.

8. Fu K, Weisenburger DD, Greiner TC, et al. Cyclin D1negative mantle cell lymphoma: a clinicopathologic study based on gene expression profiling. Blood. 2005;106:4315-21. [CrossRef]

9. Pufall MA. Glucocorticoids and Cancer. Adv Exp Med Biol. 2015;872:315-33. [CrossRef]

10. Guggisberg K, Jordan RC. Mantle cell lymphoma of the oral cavity: case series and comprehensive review of the literature. Oral Surg Oral Med Oral Pathol Oral Radiol Endod. 2010;109:98-104. [CrossRef] 